\title{
Serum levels of S100B and NSE proteins in Alzheimer's disease patients
}

\author{
Márcia L Chaves ${ }^{1 *}$, Ana L Camozzato ${ }^{1}$, Eduardo D Ferreira', Isabel Piazenski ${ }^{1}$, Renata Kochhann', Oscar Dall'Igna², \\ Guilherme S Mazzini ${ }^{2}$, Diogo O Souza ${ }^{2}$, Luis V Portela ${ }^{2}$
}

\begin{abstract}
Background: Alzheimer's disease is the most common dementia in the elderly, and the potential of peripheral biochemical markers as complementary tools in the neuropsychiatric evaluation of these patients has claimed further attention.

Methods: We evaluated serum levels of S100B and neuron-specific enolase (NSE) in 54 mild, moderate and severe Alzheimer's disease (AD) patients and in 66 community-dwelling elderly. AD patients met the probable NINCDSADRDA criteria. Severity of dementia was ascertained by the Clinical Dementia Rating (CDR) scale, cognitive function by the Mini Mental State Examination (MMSE), and neuroimage findings with magnetic resonance imaging. Serum was obtained from all individuals and frozen at $-70^{\circ} \mathrm{C}$ until analysis.
\end{abstract}

Results: By comparing both groups, serum S100B levels were lower in AD group, while serum NSE levels were the same both groups. In AD patients, S100B levels were positively correlated with CDR scores (rho $=0.269 ; p=0.049$ ) and negatively correlated with MMSE scores (rho $=-0.33 ; P=0.048$ ). NSE levels decreased in AD patients with higher levels of brain atrophy.

Conclusions: The findings suggest that serum levels of S100B may be a marker for brain functional condition and serum NSE levels may be a marker for morphological status in AD.

\section{Background}

Alzheimer's disease (AD) is a progressive brain disorder that results in memory impairment, personality alterations, global cognitive dysfunction, and functional impairments [1]. It is the most common dementia in the elderly, accounting for $60-80 \%$ of cases, and it is estimated to affect more than 4 million of USA citizens [2]. The lifespan of individuals diagnosed with AD is reduced by about $50 \%$ as compared with those of similar age without disease, and the survival expectancy is negatively associated with the severity of the disease at the time of diagnosis [3]. Furthermore, there is no definitive ante-mortem diagnostic test for $\mathrm{AD}$, and when the clinical diagnosis is made, is difficult to access and following the course of neural cells loss [4].

The inherent hurdles of studying brain tissues in human populations, especially in vivo, are the

\footnotetext{
* Correspondence: mchaves@hcpa.ufrgs.br

${ }^{1}$ Serviço de Neurologia, Hospital de Clínicas de Porto Alegre, Rua Ramiro Barcelos 2350, 90035-003 Porto Alegre, RS, Brazil
}

permanent stimulus for finding peripheral markers of central nervous system (CNS) alterations. In this context, a number of proteins have been proposed as peripheral biochemical markers of neuronal damage and glial injury/activation, which peripheral assessment may represent a relevant step forward in the diagnostic and monitoring of CNS diseases [5-9]. For this reason, the clinical usefulness of peripheral biochemical markers as complementary tool in the neuropsychiatric evaluation has claimed further attention.

S100B and neuron specific enolase (NSE) are brain derived proteins extensively studied as peripheral biochemical markers for brain injury [8-11]. S100B is a calcium binding protein physiologically produced and released predominantly by astrocytes, whereas NSE is a cytoplasmatic glycolytic pathway enzyme, being the $\gamma \gamma$ isoform mainly neuronal $[12,13]$. Since their levels may increase in CSF and/or blood in several brain pathologies, both proteins are considered to be markers of astrocytic damage/reaction (S100B) and neuronal damage (NSE) [14-16]. Considering the prominent 
neural death observed in the course of $\mathrm{AD}$, some studies have also attempted to clinically evaluate the levels of these proteins, resulting in contradictory findings [17-21], but alternatively, experimental and human studies have strengthened the belief that S100B is implicated in the mechanisms underlying neurodegeneration in AD [22-24]. Accordingly, it was reported an association between the deposition of cerebral amyloid beta protein and the presence of activated astrocytes over expressing S100B.

Furthermore, life-long over expression of S100B in Down syndrome patients and transgenic mice cause neuronal and glial morphological alterations similar to those found in AD patients, as well as behavioral deficits in animals [17-19]. These conjectures have been the rational for studying CSF/serum S100B and NSE levels in $\mathrm{AD}$ as markers of neurodegeneration and severity of the disease. Also, it is important to take into account that, due to the insufficiency of professional, methodological and background conditions, the diagnosis of $\mathrm{AD}$ in non specialized centers may not be accurately performed, which encourage identifying potential peripheral biomarkers for $\mathrm{AD}$, aiming an easier, accurate and widespread diagnosis [4].

The major aim of our study was to evaluate serum S100B and NSE levels (more readily assessed than CSF) in AD patients and control elderly individuals without pathological cognitive impairment. In addition, we searched for correlations among their levels and the severity of dementia, cognitive status and brain morphological changes accessed by MRI.

\section{Methods}

\section{Participants and study design}

A cross-sectional study with AD patients and control community-dwelling elderly was carried out. Thirty six AD patients met the probable NINCDS ADRDA criteria [25] and were recruited from the Neurogeriatric outpatient clinic of Hospital de Clínicas de Porto Alegre (HCPA), Porto Alegre, RS, Brazil. Severity of dementia was assigned with the Clinical Dementia Rating (CDR) scale and the cognitive status was assessed by Mini Mental State Examination (MMSE) [26-28]. The CDR is a scale in which $\mathrm{CDR}=0$ denotes no cognitive impairment, and the remaining points indicate various stages of dementia: $\mathrm{CDR}=1$ - mild dementia, $\mathrm{CDR}=2$ - moderate dementia, and CDR $=3$ - severe dementia. Exclusion criterion for patients was the presence of any other neurological or psychiatric condition (except if associated with $\mathrm{AD}$ ), or diseases that could lead to confusion in the diagnosis of $\mathrm{AD}$.

A control group composed of 66 community-dwelling elderly individuals was recruited from the catchment's area of the same hospital. The inclusion criteria were age higher than 60 years and a $C D R=0$. Controls were excluded if they presented chronic renal disease, history of significant head injury or stroke; other psychiatric conditions such as major affective disorder or evidence of current depression; uncorrectable vision or hearing loss or other conditions such as substance abuse or use of medications that could impair cognitive function.

$\mathrm{AD}$ patients were evaluated with brain magnetic resonance imaging. Patients were additionally submitted to a complete medical and laboratory evaluation. Educational attainment was checked for all participants.

Blood samples $(3 \mathrm{ml})$ for S100B and NSE levels measurement were collected by venipuncture with a tube (vacuum system) without anticoagulants by a trained professional. Serum (was obtained by centrifugation at $5,000 \times g$ for $5 \mathrm{~min}$ and, soon thereafter, it was frozen at $-70^{\circ} \mathrm{C}$ until analysis.

\section{Brain MRI}

Neuroimaging data were acquired with MRI equipments of 1.5 T (Siemens Magneton Vision Plus or Siemens Symphony, Siemens Medical Systems, Erlang, Germany) with the axial SE and TSE pulse sequences, in T2, (TR: 7,100; TE: 115; slice width: $5 \mathrm{~mm}$; FOV: 230; matrix: $345 \times 512$ ), FLAIR (TR: 9,000; TE: 110; slice width: 5 mm; FOV: 230; matrix: $154 \times 256)$ and IR (TR: 1,450 , TE: 115 , slice width: $3 \mathrm{~mm}$, FOV: 200 ; matrix: $160 \times$ 256). Sagital SE images were also acquired in T1 (TR: 580; TE: 14; slice width: $5 \mathrm{~mm}$; FOV: 260; matrix: $156 \times$ 256). The average duration of the exam was 30 minutes.

Degree of brain atrophy was measured according to the method of Meese et al. 1980 [29]. Two transversal lines were established in the axial plane of the brain, on TSE pulse sequence, in T2. The first estimated the latero-lateral diameter of the lateral ventricles (D1), and the second, between the parietal bones. The brain atrophy index (BAI) was calculated by the equation $\mathrm{BAI}=$ 10 - (D2/D1).

Three degrees of brain atrophy were also established: mild (level 1), moderate (level 2), and severe (level 3), based on the 25,50 and 75 percentile values of the groups combined.

\section{Serum S100B and NSE analyses}

A quantitative monoclonal two-site immunoluminometric assay LIA-mat Sangtec 100 (BYK-Sangtec, Germany), was used for measuring S100B levels in 100 ( $\mathrm{L}$ of samples. The immunoluminometric assay is composed of three monoclonal antibodies specific to subunit $\beta$ of $\mathrm{S} 100$ and a tracer antibody, which is bound to isoluminol. Oxidation of isoluminol is started by injection of an alkaline peroxide solution and catalyst solution. The immunological reaction is detected by light reaction [30]. The determinations were carried out in two different experiments. The S100B 
calibration curve was linear up to $20(\mu \mathrm{g} / \mathrm{L}$, and the CVs for duplicates across the entire concentration range for the calibrators and samples were $<5 \%$. The detection limit of the assay is $0.02(\mu \mathrm{g} / \mathrm{L}$, as provided by the supplier of the LIA-mat Sangtec 100 assay. Internal controls provided by manufacturer was used to determine inter- assay variation, which was also $<5 \%$. S100B levels are expressed as mean \pm standard deviation.

NSE level was evaluated in serum samples by an electrochemiluminescence assay kit (ECLIA, Roche Diagnostics, USA). This is a quantitative method that uses a monoclonal antibody specific for NSE and labeled with a ruthenium complex, which produces light emission when excited [6]. Reactions and quantification were performed in duplicate by a fully automatized equipment Elecsys-2010 (Roche Diagnostics Corporation ${ }^{\circ}$ ). Internal software and controls provided by the manufacturer allow controlling the quality of assay. The NSE calibration curve was linear up to $370(\mu \mathrm{g} / \mathrm{L})$, and the CVs for duplicates across the entire concentration range for the calibrators, controls and samples were $<5 \%$. The detection limit was $0.015 \mu \mathrm{g} / \mathrm{L}$. Serum NSE level is expressed as $\mu \mathrm{g} / \mathrm{L}$ (mean \pm S.D.).

\section{Ethical aspects}

The study was conducted in accordance with the Declaration of Helsinki, and was approved by the Ethics Committee for Medical Research of the university hospital where it was developed. Informed consent was obtained from the subjects, their nearest relatives, or both.

\section{Statistical analysis}

Descriptive statistics are presented with mean \pm standard deviation for parametric variables, and absolute and percentage frequency for categories. Comparison of S100B and NSE serum levels between groups was made using one-way ANOVA with Tukey test, and Student's t test for independent samples. Correlation between S100B and MMSE was performed with Spearman's coefficient. Chi-square test with Yates or Fisher exact correction was used for the analysis of association of CDR and MRI findings categories. Comparison ANOVA followed by Tukey test and Student $t$ test were used to analyze differences between serum levels of S100B (AD and controls) and CDR groups. A $p$ value $<0.05$ was considered statistically significant. Statistical analyses were carried out with the SPSS 16.0 for Windows.

\section{Results}

\section{Comparisons between $A D$ and Control group}

The demographic, clinical and biochemical characteristics of AD patients and control elderly group are depicted in Table 1. The MMSE and CDR scales were altered in $\mathrm{AD}$ patients compared to control group.
Table 1 Demographic, clinical and biochemical data of subjects.

\begin{tabular}{|c|c|c|c|}
\hline & $\begin{array}{l}\text { Control group } \\
\quad(N=66)\end{array}$ & $\begin{array}{l}\text { AD patients } \\
(\mathrm{N}=54)\end{array}$ & $P$ value \\
\hline Age (years) (mean $\pm S D)$ & $76.56 \pm 5.46$ & $77.13 \pm 7.57$ & 0.773 \\
\hline \multicolumn{4}{|l|}{ Gender } \\
\hline Male (\%) & $20(30 \%)$ & $18(33 \%)$ & 0.681 \\
\hline Female (\%) & $46(70 \%)$ & $36(67 \%)$ & \\
\hline Education (in years) & $8.48 \pm 5.24$ & $5.23 \pm 4.38$ & 0.01 \\
\hline MMSE (mean \pm SD) & $27.09 \pm 2.99$ & $10.98 \pm 6.44$ & 0.001 \\
\hline \multicolumn{4}{|l|}{ CDR (\%) } \\
\hline 0 & $66(100 \%)$ & - & 0.001 \\
\hline 1 (mild) & - & $12(22 \%)$ & \\
\hline 2 (moderate) & - & $22(41 \%)$ & \\
\hline 3 (severe) & - & $20(37 \%)$ & \\
\hline $\mathrm{S} 100 \mathrm{~B}(\mu \mathrm{g} / \mathrm{l})($ mean $\pm \mathrm{SD})$ & $0.21 \pm 0.36$ & $0.08 \pm 0.06$ & 0.008 \\
\hline NSE $(\mu \mathrm{g} / \mathrm{l})($ mean $\pm \mathrm{SD})$ & $9.54 \pm 5.28$ & $9.28 \pm 3.86$ & 0.832 \\
\hline
\end{tabular}

MMSE: Mini Mental State Examination. CDR: Clinical Dementia Rating

There was a statistically significant difference in serum S100B levels between AD and control group (0.08 \pm 0.06 vs. $0.21 \pm 0.36, \mu \mathrm{g} / \mathrm{L}$, respectively; $\mathrm{p}=0.008$ ), while the serum NSE levels were similar in both groups $(9.28$ \pm 3.86 vs. $9.54 \pm 5.28, \mu \mathrm{g} / \mathrm{L}$, respectively; $\mathrm{p}=0.832$ ). Serum S100B and NSE levels did not vary with age (data not shown).

\section{Serum S100B and NSE levels in AD patients}

A positive significant correlation among CDR scores and S100B levels was observed among AD patients (rho = $0.269 ; \mathrm{p}=0.049$, data not shown). Additionally, among AD patients, there was a statistically significant difference in serum S100B levels between mild and severe CDR scores $(0.050 \pm 0.013$ vs. $0.091 \pm 0.022$, respectively; $\mathrm{p}=0.022$ ) (Figure 1 ). No differences in serum NSE level were observed among CDR categories of AD patients (data not shown).

There was a significant negative correlation between serum S100B levels and cognitive performance expressed as a positive correlation between S100B levels and MMSE score (Spearman correlation rho $=-0.35 ; \mathrm{p}$ $=0.01$; Figure 2). A negative correlation between serum NSE levels and MMSE was also observed (Spearman correlation rho $=-0.48 ; \mathrm{p}=0.017$, data not shown).

\section{MRI and S100 and NSE serum levels in AD patients}

Table 2 shows the correlation among serum NSE and S100B levels with the degree of brain atrophy accessed by MRI in AD patients. NSE levels significantly decreased with the brain atrophy severity. Serum S100B levels were not affected by brain atrophy. Despite literature suggest the opposite [31]; there was no correlation among severity of dementia (evaluated by CDR scale) and the MRI findings (Table 3). 


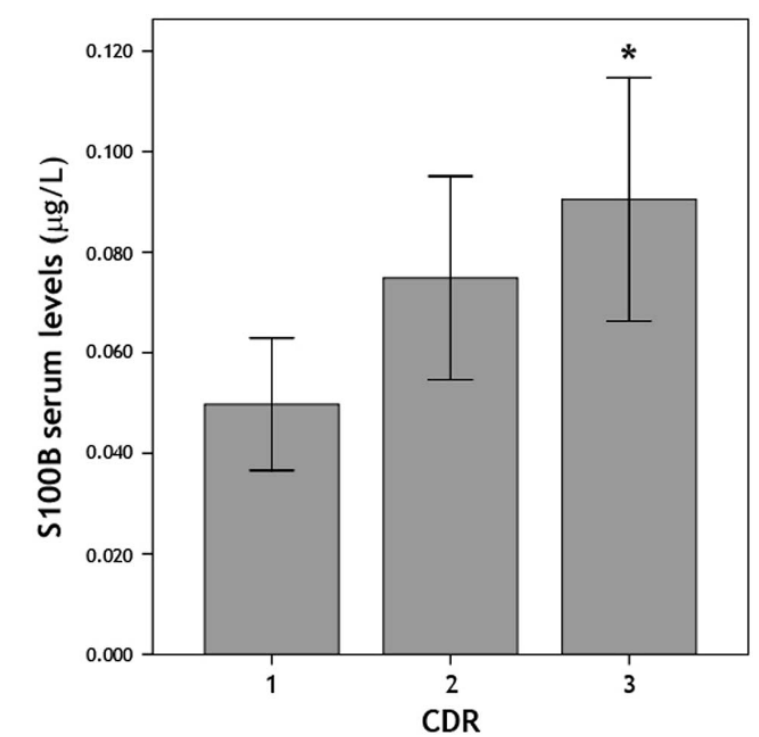

Figure 1 Serum S100B level (mean \pm SD) according to severity of dementia in AD (CDR scale; 1 mild, 2 moderate; 3 severe) One-way ANOVA $(F=3.685)$

\section{Discussion}

The main goal of this work was to investigate the course of brain neurodegenerative processes in AD patients through biochemical brain markers, neuropsychological and neuroimaging evaluations. Our main findings were: i) although serum NSE levels were not different between AD patients and control elderly individuals, serum of S100B levels were significantly lower in DA patients; ii)

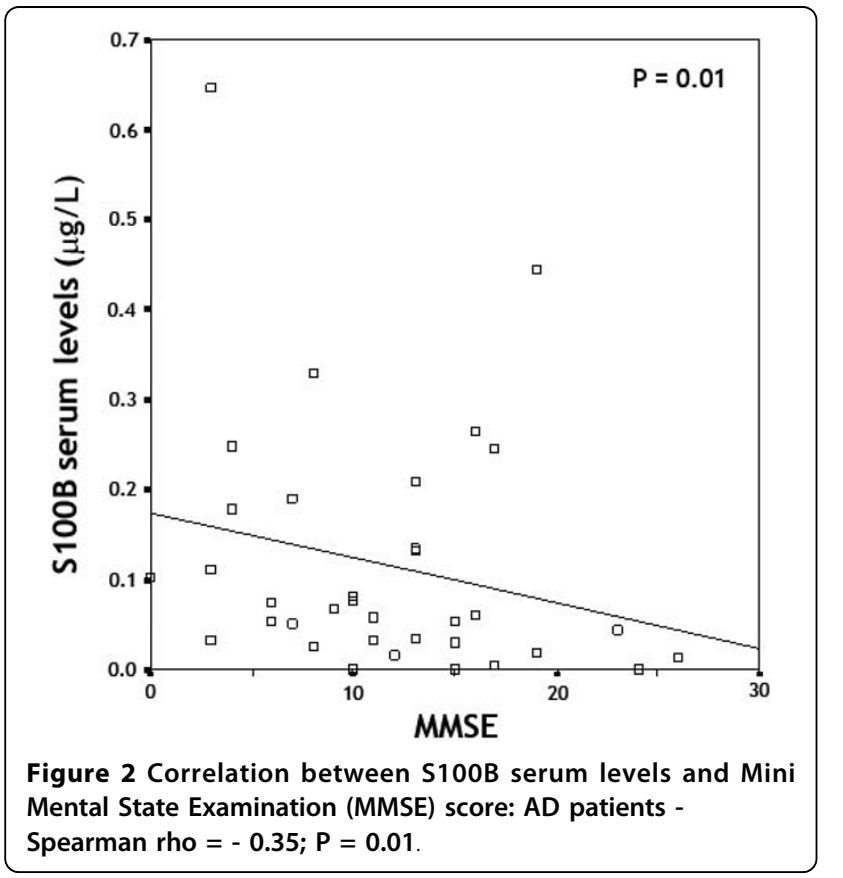

Table 2 Serum S100B and NSE levels (mean \pm SD) according to brain MRI findings in AD patients.

\begin{tabular}{|c|c|c|c|}
\hline & \multicolumn{3}{|c|}{ Degree of brain atrophy } \\
\hline & $\begin{array}{l}\text { Percentil } 25 \\
(N=16)\end{array}$ & $\begin{array}{l}\text { Percentil } 50 \\
(N=26)\end{array}$ & $\begin{array}{l}\text { Percentil } 75 \\
(\mathrm{~N}=12)\end{array}$ \\
\hline S100B & $0.09 \pm 0.05$ & $0.07 \pm 0.06$ & $0.07 \pm 0.06$ \\
\hline NSE & $14.52 \pm 4.08^{a, b}$ & $7.98 \pm 1.52^{a, c}$ & $6.64 \pm 1.17^{b, c}$ \\
\hline
\end{tabular}

$a \neq a: p<0.001$

$b \neq b: p=0.001$

$c \neq c: p=0.077$

there were a positive correlation between S100B levels and AD severity (evaluated by CDR and MMSE) as well as a negative correlation between NSE levels and the severity of morphological brain alterations, evaluated by MRI.

In the last years the possibility of evaluating brain damage/activity through quantification of neuronal and glial derived proteins (such as S100B and NSE) in peripheral samples has gained appropriate attention in clinical and experimental settings $[5,14,20,32]$. However, S100B and NSE proteins are also expressed in other non neural cell types under physiological and pathological conditions. Thus, the brain specificity of these proteins has been questionable by some works, including from our laboratory [33], when assessing serum samples. Moreover, recent epidemiological and clinico-pathologic data suggest overlaps between $\mathrm{AD}$ and cerebrovascular lesions that may magnify the effect of mild AD pathology and promote progression of cognitive decline or even may precede neuronal damage and dementia [34]. So, we cannot rule out that vascular lesions also could account for increase S100B levels.

Despite the controversies on their brain specificity, S100B and NSE have been investigated in different brain diseases as peripheral markers of therapeutic interventions, as well as of neurological and neuropsychological outcome [14,16,22-24]. Additionally, a recent work suggests that blood-brain barrier permeability may also be damaged even at an early stage of AD indicating different blood-brain-CSF compartmental kinetics [35]. Thus, the leakage of proteins from brain to blood could be facilitated.

Table 3 Distribution of dementia severity (CDR categories) according to brain MRI findings in AD patients.

\begin{tabular}{|c|c|c|c|}
\hline \multirow[t]{2}{*}{ CDR } & \multicolumn{3}{|c|}{ Degree of brain atrophy } \\
\hline & $\begin{array}{l}\text { Percentil } 25 \\
(\mathrm{~N}=16)\end{array}$ & $\begin{array}{c}\text { Percentil } 50 \\
(\mathrm{~N}=26)\end{array}$ & $\begin{array}{c}\text { Percentil } 75 \\
(\mathrm{~N}=12)\end{array}$ \\
\hline Mild $(\mathrm{N}=12)$ & $3(19 \%)$ & $7(27 \%)$ & $2(17 \%)$ \\
\hline Moderate $(\mathrm{N}=22)$ & $7(44 \%)$ & $8(31 \%)$ & $7(58 \%)$ \\
\hline Severe $(N=20)$ & $6(37.5 \%)$ & $11(42 \%)$ & $3(25 \%)$ \\
\hline
\end{tabular}


There is a considerable number of clinical studies regarding CSF levels of S100B in $\mathrm{AD}$, which from the perspective of cerebral protein release provides more sensitivity and specificity than serum samples, however, the availability of CSF samples is somewhat limited for routine clinical use $[20,21,36]$. These previous studies showed discrepant results with respect to the differences in S100B levels between $\mathrm{AD}$ and control groups and also to clinical associations. While some studies have reported increased CSF levels of S100B in AD patients compared to controls $[21,36]$, others did not find any difference [20]. There are also reports suggesting a positive correlation between CSF S100B levels and MMSE, and a negative correlation with severity of dementia by CDR scale [20] while in others CSF S100B levels did not correlate with impaired cognitive status evaluated by MMSE [21,36].

In contrast to these cited works, here we demonstrated AD patients a positive correlation between serum S100B levels and brain function (evaluated by MMSE and CDR). Ethnic differences, education, prior life style and the predominance of female in our study, compared to others, could account for the differences observed among the previous published results. Considering that in our work MMSE and CDR scales identified patients with impaired cerebral functionality affected by $\mathrm{AD}$ and that the S100B levels were higher in more severely affected patients, we preliminarily suggest that serum S100B levels could help to distinguish severity or to follow up the progression of dementia in AD disease, even though the diagnosis is based on clinical investigations. This result may reflect the participation of this protein in the pathogenesis of AD. Indeed, glial cells particularly microglia and astrocytes are able to modulate cerebral plasticity and to protect brain from insults [13]; thus, in this context the increase in S100B could indicate astrocytic reaction to neuronal injury (reactive astrogliosis) in AD patients. Once activated, these cells increase the expression of substances that can participate in the excitotoxicity and inflammatory processes that occur during the evolution of $\mathrm{AD}$ [37].

Further, dysfunction of glial cells may promote neurodegeneration and, eventually, the retraction of neuronal synapses, which leads to cognitive deficits [38]. However, our major concern is regarding the decreasing levels of $\mathrm{S} 100 \mathrm{~B}$ in total AD group compared to controls. This finding was confirmed by an additional experiment with a new set of patients. Interestingly, the severity of CDR score was associated with elevations in serum S100B levels, contrasting to our previous findings with schizophrenic patients [39], when the levels were more elevated in the early onset of disease. In this context, increased astrocytic expression of S100B could be involved in the progression of brain neuropathological changes and behavioral deficits observed in patients and animal models [20,13,40-42]. While in this study S100B levels in AD patients did not correlate with brain morphological changes evaluated by MRI, lower serum levels of NSE were related to higher degree of atrophy and brain macroscopic alterations. Furthermore, this loss was not associated with dementia severity in AD patients. The lack of a correlation with atrophy and cognition reported here is somewhat curious as many recent reports of the literature suggest the opposite [31].

Levels of NSE have been shown to be elevated in acute phase of several disorders of the CNS [43-47]. This data could preliminary suggest that AD patients, prior the onset of symptoms, could have altered NSE levels, which is now reflected by brain atrophy and ventricle enlargement. However, the reports of CSF NSE vary from decreased levels [17], no difference [19] to increased levels [48]. Interestingly, Palumbo et al. 2008 [48] showed that CSF NSE level has the same behavior as the other accepted markers of $\mathrm{AD}$, being correlated with Abeta42 and total protein tau (h-tau).

Taking into consideration, the strong association of the prognosis of $\mathrm{AD}$ patients with the severity of dementia at the diagnosis [3], and the difficulty of evaluating the degree of neural cells loss in AD [4], further experimental and clinical studies regarding these serum markers in AD disease should be encouraged.

\section{Conclusions}

In conclusion, we showed that in $\mathrm{AD}$ patients the serum S100B levels increased with the severity of the disease whereas decreased serum levels of NSE were associated with increased brain morphological damage.

\section{Acknowledgements}

Coordenação de Aperfeiçoamento de Pessoal de Nível Superior (CAPES), Fundação de Amparo à Pesquisa do Rio Grande do Sul (FAPERGS) and Conselho Nacional de Desenvolvimento Científico e Tecnológico (CNPq), IBN.Net/Finep, INCT for Excitotoxicity and Neuroprotection/CNPq.

\section{Author details \\ 'Serviço de Neurologia, Hospital de Clínicas de Porto Alegre, Rua Ramiro Barcelos 2350, 90035-003 Porto Alegre, RS, Brazil. ²Programa de Pós- graduação em Bioquímica, PPG-Bioq. Departamento de Bioquímica, ICBS, UFRGS, Ramiro Barcelos 2600, anexo, 90035-003 Porto Alegre, RS, Brazil.}

\section{Authors' contributions}

MLC designed the study, was responsible for the statistical design of the study, supervised the data collection, and wrote the manuscript. ALC was responsible for carrying out the statistical analysis and helped with reviewing the manuscript. EDF supervised the data collection, was responsible for carrying out the statistical analysis and wrote the manuscript. IP, RK, OD and GSM collected the data and assisted with writing the manuscript. DOS and LVP designed the study, made the biochemical measurements and reviewed the manuscript. All authors read and approved the final manuscript.

Competing interests

The authors declare that they have no competing interests. 
Received: 4 May 2009

Accepted: 27 January 2010 Published: 27 January 2010

\section{References}

1. Juva K, Sulkava R, Erkinjuntti T, Ylikoski R, Valvanne J, Tilvis R: Staging the severity of dementia: comparison of clinical (CDR, DSM-III-R), functional (ADL, IADL) and cognitive (MMSE) scales. Acta Neurol Scand 1994 90:293-298.

2. Hebert LE, Scherr PA, Bienias JL, Bennett DA, Evans DA: Alzheimer disease in the US population: prevalence estimates using the 2000 census. Arch Neurol 2003, 60:1119-1122.

3. Larson EB, Shadlen MF, Wang L, McCormick WC, Bowen JD, Teri L, Kukull WA: Survival after initial diagnosis of Alzheimer disease. Ann Intern Med 2004, 140:501-509.

4. Growdon JH: Biomarkers of Alzheimer disease. Arch Neurol 1999 56:281-283.

5. Machado-Vieira R, Dietrich MO, Leke R, Cereser VH, Zanatto V, Kapczinski F, Souza DO, Portela LV, Gentil V: Decreased plasma brain derived neurotrophic factor levels in unmedicated bipolar patients during manic episode. Biol Psychiatry 2007, 61:142-144.

6. Oses JP, Leke R, Portela LV, Lara DR, Schmidt AP, Casali EA, Wofchuk S, Souza DO, Sarkis JJ: Biochemical brain markers and purinergic parameters in rat CSF after seizure induced by pentylenetetrazol. Brain Res Bull 2004, 64:237-242.

7. Herrmann M, Jost S, Kutz S, Ebert AD, Kratz T, Wunderlich MT, Synowitz H: Temporal profile of release of neurobiochemical markers of brain damage after traumatic brain injury is associated with intracranial pathology as demonstrated in cranial computerized tomography. $J$ Neurotrauma 2000, 17:113-122.

8. Wunderlich MT, Wallesch CW, Goertler M: Release of glial fibrillary acidic protein is related to the neurovascular status in acute ischemic stroke. Eur J Neurol 2006, 13:1118-1123.

9. Schaf DV, Tort AB, Fricke D, Schestatsky P, Portela LV, Souza DO, Rieder CR S100B and NSE serum levels in patients with Parkinson's disease. Parkinsonism Relat Disord 2005, 11:39-43.

10. Herrmann M, Ebert AD, Galazky I, Wunderlich MT, Kunz WS, Huth C: Neurobehavioral outcome prediction after cardiac surgery: role of neurobiochemical markers of damage to neuronal and glial brain tissue. Stroke 2000, 31:645-650.

11. Busnello JV, Leke R, Oses JP, Feier G, Bruch R, Quevedo J, Kapczinski F Souza DO, Portela LV: Acute and chronic electroconvulsive shock in rats: effects on peripheral markers of neuronal injury and glial activity. Life Sci 2006, 78:3013-3017.

12. Kaiser $E$, Kuzmits $R$, Pregant $P$, Burghuber O, Worofka W: Clinical biochemistry of neuron specific enolase. Clin Chim Acta 1989, 183:13-32.

13. Van Eldik LJ, Wainwright MS: The Janus face of glial-derived S100B: beneficial and detrimental functions in the brain. Restor Neurol Neurosci 2003, 21:97-108.

14. Herrmann $M$, Ehrenreich $\mathrm{H}$ : Brain derived proteins as markers of acute stroke: their relation to pathophysiology, outcome prediction and neuroprotective drug monitoring. Restor Neurol Neurosci 2003, 21:177-190.

15. Steiner J, Bielau H, Bernstein HG, Bogerts B, Wunderlich MT: Increased cerebrospinal fluid and serum levels of $\mathrm{S} 100 \mathrm{~B}$ in first-onset schizophrenia are not related to a degenerative release of glial fibrillar acidic protein, myelin basic protein and neurone-specific enolase from glia or neurones. J Neurol Neurosurg Psychiatry 2006, 77:1284-1287.

16. Rothermundt M, Ohrmann P, Abel S, Siegmund A, Pedersen A, Ponath G, Suslow T, Peters M, Kaestner F, Heindel W, Arolt V, Pfleiderer B: Glial cell activation in a subgroup of patients with schizophrenia indicated by increased S100B serum concentrations and elevated myo-inositol. Prog Neuropsychopharmacol Biol Psychiatry 2007, 31:361-364

17. Cutler NR, Kay AD, Marangos PJ, Burg C: Cerebrospinal fluid neuronspecific enolase is reduced in Alzheimer's disease. Arch Neurol 1986, 43:153-154.

18. Blennow K, Wallin A, Ekman R: Neuron specific enolase in cerebrospinal fluid: a biochemical marker for neuronal degeneration in dementia disorders?. J Neural Transm Park Dis Dement Sect 1994, 8:183-191.

19. Parnetti L, Palumbo B, Cardinali L, Loreti F, Chionne F, Cecchetti R, Senin U: Cerebrospinal fluid neuron-specific enolase in Alzheimer's disease and vascular dementia. Neurosci Lett 1995, 183:43-45.
20. Whitaker-Azmitia PM, Wingate M, Borella A, Gerlai R, Roder J, Azmitia EC: Transgenic mice overexpressing the neurotrophic factor S-100 beta show neuronal cytoskeletal and behavioral signs of altered aging processes: implications for Alzheimer's disease and Down's syndrome. Brain Res 1997, 776:51-60.

21. Griffin WS, Sheng JG, McKenzie JE, Royston MC, Gentleman SM, Brumback RA, Cork LC, Del Bigio MR, Roberts GW, Mrak RE: Life-long overexpression of S100beta in Down's syndrome: implications for Alzheimer pathogenesis. Neurobiol Aging 1998, 19:401-405.

22. Mrak RE, Griffin WS: The role of activated astrocytes and of the neurotrophic cytokine S100B in the pathogenesis of Alzheimer's disease. Neurobiol Aging 2001, 22:915-922.

23. Peskind ER, Griffin WS, Akama KT, Raskind MA, Van Eldik LJ: Cerebrospinal fluid S100B is elevated in the earlier stages of Alzheimer's disease. Neurochem Int 2001, 39:409-413.

24. Petzold A, Jenkins R, Watt HC, Green AJ, Thompson EJ, Keir G, Fox NC, Rossor MN: Cerebrospinal fluid S100B correlates with brain atrophy in Alzheimer's disease. Neurosci Lett 2003, 336:167-170.

25. McKhann G, Drachman D, Folstein M, Katzman R, Price D, Stadlan EM: Clinical diagnosis of Alzheimer's disease: report of NINCDS-ADRDA Work Group under the auspices of Department of Health and Human Services Task Force on Alzheimer's Disease. Neurology 1984, 34:939-944.

26. Folstein MF, Folstein SE, McHugh PR: "Mini-mental state". A practical method for grading the cognitive state of patients for the clinician. $J$ Psychiatr Res 1975, 12:189-198.

27. Chaves ML, Izquierdo I: Differential diagnosis between dementia and depression: a study of efficiency increment. Acta Neurol Scand 1992 85:378-382.

28. Chaves ML, Camozzato AL, Godinho C, Kochhann R, Schuh A, de Almeida VL, Kaye J: Validity of the Clinical Dementia Rating Scale for The Detection and Staging of Dementia in Brazilian Patients. Alzheimer Dis Assoc Disord 2007, 21:210-217.

29. Meese W, Kluge W, Grumme T, Hopfenmuller W: CT evaluation of the CSF spaces of healthy persons. Neuroradiology 1980, 19:131-136.

30. Portela LV, Tort AB, Schaf DV, Ribeiro L, Nora DB, Walz R, Rotta LN, Silva CT, Busnello JV, Kapczinski F, Gonçalves CA, Souza DO: The serum S100B concentration is age dependent. Clin Chem 2002, 48:950-952.

31. Davatzikos C, Xu F, An Y, Fan Y, Resnick SM: Longitudinal progression of Alzheimer's-like patterns of atrophy in normal older adults: the SPAREAD index. Brain 2009, 132:2026-2035.

32. Busnello JV, Oses JP, da Silva RS, Feier G, Barichello T, Quevedo J, Böhmer AE, Kapczinski F, Souza DO, Sarkis JJ, Portela LV: Peripheral nucleotide hydrolysis in rats submitted to a model of electroconvulsive. Prog Neuropsychopharmacol Biol Psychiatry 2008, 32:1829-1833.

33. Mazzini GS, Souza DO, Portela LV: The ischemic heart as an extracerebral source for S100B. Resuscitation 2009, 80:144.

34. Jellinger KA: Alzheimer disease and cerebrovascular pathology: an update. J Neural Transm 2002, 109:813-836.

35. Starr JM, Farrall AJ, Armitage P, McGurn B, Wardlaw J: Blood-brain barrier permeability in Alzheimer's disease: a case-control MRI study. Psychiatry Res 2009, 171:232-241.

36. Green AJ, Harvey RJ, Thompson EJ, Rossor MN: Increased S100beta in the cerebrospinal fluid of patients with frontotemporal dementia. Neurosci Lett 1997, 235:5-8.

37. Farfara D, Lifshitz V, Frenkel D: Neuroprotective and neurotoxic properties of glial cells in the pathogenesis of Alzheimer's disease. J Cell Mol Med 2008, 12:762-780.

38. Schwab C, McGeer PL: Inflammatory aspects of Alzheimer disease and other neurodegenerative disorders. J Alzheimers Dis 2008, 13:359-369.

39. Lara DR, Gama CS, Belmonte-de-Abreu P, Portela LV, Gonçalves CA, Fonseca M, Hauck S, Souza DO: Increased serum S100B protein in schizophrenia: a study in medication-free patients. J Psych Res 2001, 35:11-14.

40. Marshak DR, Pesce SA, Stanley LC, Griffin WS: Increased S100 beta neurotrophic activity in Alzheimer's disease temporal lobe. Neurobiol Aging 1992, 13:1-7.

41. Sheng JG, Mrak RE, Griffin WS: S100 beta protein expression in Alzheimer disease: potential role in the pathogenesis of neuritic plaques. J Neurosci Res 1994, 39:398-404

42. Mrak RE, Griffin WS: Trisomy 21 and the brain. J Neuropathol Exp Neurol 2004, 63:679-685. 
43. Hay E, Royds JA, Davies-Jones GA, Lewtas NA, Timperley WR, Taylor CB: Cerebrospinal fluid enolase in stroke. J Neurol Neurosurg Psychiatry 1984, 47:724-729.

44. Persson L, Hardemark HG, Gustafsson J, Rundstrom G, Mendel-Hartvig I, Esscher T, Pahlman S: S-100 protein and neuron-specific enolase in cerebrospinal fluid and serum: markers of cell damage in human central nervous system. Stroke 1987, 18:911-918.

45. Roine RO, Somer H, Kaste M, Viinikka L, Karonen SL: Neurological outcome after out-of-hospital cardiac arrest. Prediction by cerebrospinal fluid enzyme analysis. Arch Neurology 1989, 46:753-756.

46. Studahl M, Rosengren L, Gunther $G$, Hagberg L: Difference in pathogenesis between herpes simplex virus type 1 encephalitis and tick-borne encephalitis demonstrated by means of cerebrospinal fluid markers of glial and neuronal destruction. J Neurol 2000, 247:636-642.

47. Correale J, Rabinowicz AL, Heck CN, Smith TD, Loskota WJ, DeGiorgio CM: Status epilepticus increases CSF levels of neuron-specific enolase and alters the blood-brain barrier. Neurology 1998, 50:1388-1391.

48. Palumbo B, Siepi D, Sabalich I, Tranfaglia C, Parnetti L: Cerebrospinal fluid neuron-specific enolase: a further marker of Alzheimer's disease?. Funct Neurol 2008, 23:93-96.

doi:10.1186/1742-2094-7-6

Cite this article as: Chaves et al: Serum levels of S100B and NSE

proteins in Alzheimer's disease patients. Journal of Neuroinflammation 2010 7:6.

\section{Submit your next manuscript to BioMed Central and take full advantage of:}

- Convenient online submission

- Thorough peer review

- No space constraints or color figure charges

- Immediate publication on acceptance

- Inclusion in PubMed, CAS, Scopus and Google Scholar

- Research which is freely available for redistribution

Submit your manuscript at www.biomedcentral.com/submit 